\title{
Impact of Some Probiotic Bacteria on Flavor and Quality of Novel Cheese Slurry
}

\author{
Ismail, E. A; El-Alfy M. B.; Shenana, M.E. and Al-Dubai*, N. S.M \\ Dairy Sci. Dept., Fac. Agric., Moshtohor, Benha University \\ * Food Sci. and Technology Dept., Fac. Agric., Ibb Univ., Ibb Yemen
}

Corresponding Author: e.ismail@fagr.bu.edu.eg - sayed1973@yahoo.com

\begin{abstract}
Five probiotic strains include Lactococcus lactis IS9, Bifidobacterium breve ISO8, Lactobacillus rhamnosus ISO7, Lactobacillus plantarum E and Lactobacillus plantarum ATCC14917 were studied to be used as adjunct cultures in cheese-making experiments (cheese slurry). The probiotic strains were assessed for their viability, their resistance to $\mathrm{NaCl}$ concentrations and their ability to develop $\mathrm{pH}$ and acidity. All the tested strains were used in making cheese slurry. Proteolysis and lipolysis of the cheese slurry were improved in which the proteolytic and lipolytic bacterial counts of fresh cheese slurry reached its highest counts at the end of incubation for 7 days at $40^{\circ} \mathrm{C}$. All the prepared cheese slurry had good acceptable properties during the sensory evaluation. The amino and fatty acids profiles demonstrated that the tested probiotic bacteria could be useful for making cheese slurry. Cheese slurry can be an effective vehicle for delivery of some probiotic organisms with good proteolytic and lipolytic properties to wide variety of cheese types.
\end{abstract}

Keywords: Probiotic; cheese slurry; proteolysis, fatty acids.

\section{Introduction}

Milk products containing probiotic bacteria are becoming popular due to their health promoting properties. According to Food and Agriculture Organization (FAO) of United Nations and World Health Organization (WHO) requirements, fermented milks should contain at least $10^{6} \mathrm{cfu}$ probiotics. As indicated by Stefanovic et al, (2018), cheese flavor is recognized as a balanced blend of fatty acids, organic acids, amino acids, carbonyl compounds, esters, alcohols, and sulfur compounds.

The development of cheese flavor is strongly dependent upon the starter microorganism utilized (Fitzsimons et al., 1999; Gobbetti et al., 2015 and Stefanovic et al., 2018) and appears to be under the influence of biological control of interrelated pathways. Slurry process is supposed to be one of the important and suitable procedures for the acceleration of cheese ripening where it considered as a good source of enzyme, small nitrogenous components, and free fatty acids (Abdel-Baky et al., 1982). The cheese-slurry system is applicable to a wide variety of cheese types.

Harper and Krisoffersen (1970) evaluated a cheese slurry system which permits cheese flavor development in a few days' time, in respect to its efficacy in studying cheese ripening and as a means of studying biochemical changes during the ripening process. The cheese slurry systems replicated the ripening processes in natural cheeses. Flavor development in cheese appears to be under specific biochemical control in which glutathione plays a multiple role in respect to the cheese slurry system including the disassociation of peptides, making them more available for proteolytic attack, protection of enzyme groups, and feedback control in respect to diacetyl and acetaldehyde formation, suggesting a number of operative feedback systems. Lipid, protein and carbohydrate fermentation are interrelated, and the direction of the fermentation can be influenced by the compositional balance of the milk constituents Hofi et al. (1991). Added pre-ripened full flavorslurry either to cheese milk before adding the starter, at a level of $1 \%$, or to the curd particles before hooping at a level of $1 \%$ or $2 \%$ of cheese milk weight. Cheese slurry improved the quality and the flavor development, protein degradation and fat hydrolysis of resultant cheese. Cheese with $2 \%$ slurry had the same acceptable full aged properties after 45 days against 120 days for control cheese.

This study aimed to use some probiotic bacterial strains and investigate their impact to develop cheese slurry system to be applicable to wide variety of cheese types.

\section{Materials and Methods}

\section{Materials}

Raw Milk: Fresh mixed Cow's and Buffaloe's milk (1:1) were obtained from the herds of Moshtohor, Fac., of Agric., Benha Univ.

Starter cultures: Freeze dried starter cultures include: Lactococcus lactis IS9, Bifidobacterium breve ISO8, Lactobacillus rhamnosus ISO7, and Lactobacillus plantarum $\mathbf{E}$ were obtained friendly from Institute of Microbiology, Federal Research Center for Nutrition and Food, Kiel, Germany through personal communication with Dr. El-Sayed Ismail Dairy Sci., Dept., Fac., of Agric., Moshtohor Benha Univ., Egypt. Lactobacillus plantarum ATCC14917 (16) was obtained from National Research center, Giza, Egypt. Yoghurt starter culture consisting of Streptococcus thermophilus and Lactobacillus delbrueckii subsp. bulgaricus (1:1) was obtained from Chr. Hansen's Laboratories, Copenhagen, Denmark. 
Rennet: A liquid rennet was used for making the cheese which was prepared in the Dairy Sci., Dept., Fac., of Agric., Moshtohor and used for soft white cheese making.

Salt: A commercial pure fine grade table salt was obtained from El-Naser Company, Egypt.

Potassium sorbate: Potassium sorbate was obtained from El-Gomhoria Co., Cairo Egypt.

\section{Methods}

Growth measurement of the bacterial cultures: $1 \%$ of overnight bacterial culture was inoculated in MRS broth for Lactobacillus sp, Cystain-MRS for Bifidobacterium breve and M17 for Streptococcus. All bacterial cultures were incubated at $37^{\circ} \mathrm{C}$ in water bath and the growth was measured by following the optical density (O.D.) at $620 \mathrm{~nm}$ using a photometer NANOCOLOR 500D (Macherey-Nagel, Dürem, Germany, (Ismail 2007).

\section{Preparation of Slurries and fresh curd:}

Cheese curd was prepared from cow's milk by Hofi et al. (1973). Slurries were prepared according to Abd-El-Hamid et al. (1991). The first part was used as a (Control) inoculated with $1 \%$ of yoghurt starter culture (Streptococcus thermophilus and Lactobacillus delbrueckii subsp. bulgaricus). The other 5 parts were as follows: T1: inoculated with $1 \%$ of yoghurt starter + Lactococcus lactis IS9 (1:1). T2: inoculated with $1 \%$ of yoghurt starter + Bifidobacterium breve ISO8 (1:1). T3: inoculated with $1 \%$ of yoghurt starter + Lactobacillus rhamnosus ISO7 (1:1). T4: inoculated with $1 \%$ of yoghurt starter + Lactobacillus plantarum E (1:1). T5: inoculated with $1 \%$ of yoghurt starter + Lactobacillus plantarum ATCC14917 (1:1). All the treatments were incubated at $40^{\circ} \mathrm{C}$ for 7 days. All cheese-slurry samples were analyzed when fresh and after 7 days for organoleptic properties, chemical analysis, total, proteolytic and lipolytic bacterial counts, free fatty acids, and free amino acids.

\section{Chemical analysis:}

Total Solids, Ash, Titratable Acidity, pH values, and Fat were determined according to the methodology mentioned in IDF (1987), AOAC (2012), IDF (1996) and BSI (1989), respectively.

Carbohydrate Content (CHO) of cheese-slurry samples were calculated by differences as follows: $\mathrm{CHO}=\mathrm{TS}-($ Protein + Fat + Ash $)$

Total nitrogen (T.N) and soluble nitrogen (S.N) were determined according to AOAC (2012).

Analysis of Fatty Acids Composition by GC: Fatty acids esters of cheese-slurry were prepared according to ISO 12966-2 (2011), then fatty acids fractions were analyzed using gas chromatograph (Agilent GC 6890A).
Determination of Total Amino Acids (TAA): Determination of free amino acids of cheese-slurry as described by AOAC (2016).

Microbiological examination:

Total Bacterial Count: The total bacterial counts of cheese-slurry were determined according to the American Public Health Association (APHA, 2004). Proteolytic and Lipolytic Bacterial Counts: of cheese-slurry were counted according to IDF (1991).

Sensory Evaluation: The organoleptic evaluations were done by 10 experienced food scientists of Dairy Sci., Dept., Fac., of Agric., Moshtohor, Benha Univ. Samples of cheese slurry were sensory evaluated according to the scheme described by IDF (1997).

Statistical Analysis: Statistical analysis of the obtained data was performed according to the user's guide given by SAS (1990).

\section{Results and Discussion}

Effect of $\mathrm{NaCl}$ concentration on the growth of some probiotic strains

Figs.1(a-d) Illustrates the growth rate of Lactococcus lactis IS9, Bifidobacterium breve ISO8, Lactobacillus rhamnosus ISO7, Lactobacillus plantarum $\mathrm{E}$ and Lactobacillus plantarum ATCC14917(16) in MRS broth containing different concentrations of $\mathrm{NaCl}(0,2,4$, and $6 \%)$. The obtained results in (Figure 1a) revealed that the growth rate for all experimental strains were increased with different rates in the absence of salt $(0 \% \mathrm{NaCl})$, all over the incubation time up to 8 hours. The growth rate was then decreased with more different rates by increasing the salt concentration and that decrease was proportional with the amount of sodium chloride. In general, the present results revealed that the control had always the higher growth rate followed by 2 and $4 \% \mathrm{NaCl}$ for all tested strains. Whereas the $6 \% \mathrm{NaCl}$ recorded the lowest growth rate of all tested strains which suggests inhibition impact of different $\mathrm{NaCl}$ concentrations. Such decrease could be attributed to the increase of osmolality of medium because of salt content. These results agreed with that obtained by EL-Wahsh (2013). Bifidobacterium breve ISO 8 was the more tolerant recorded the highest growth rate all over the different treatments whereas, Lactococcus lactis was the lowest salt tolerant, recorded the lowest growth rate (O.D). The wide rate differences for growth rate of tested strains were recorded at $2 \%$ followed by $6 \%$ $\mathrm{NaCl}$ (Figure 1b and c) which confirmed by ELAlfy et al (2018) they studied the effect of different sodium chloride concentrations on the viability of nine strains of probiotic bacteria, and they found that the counts of all tested strains were decreased with increasing salt concentration up to $4 \%$. These results will be useful during using these probiotic strains in cheese making. 

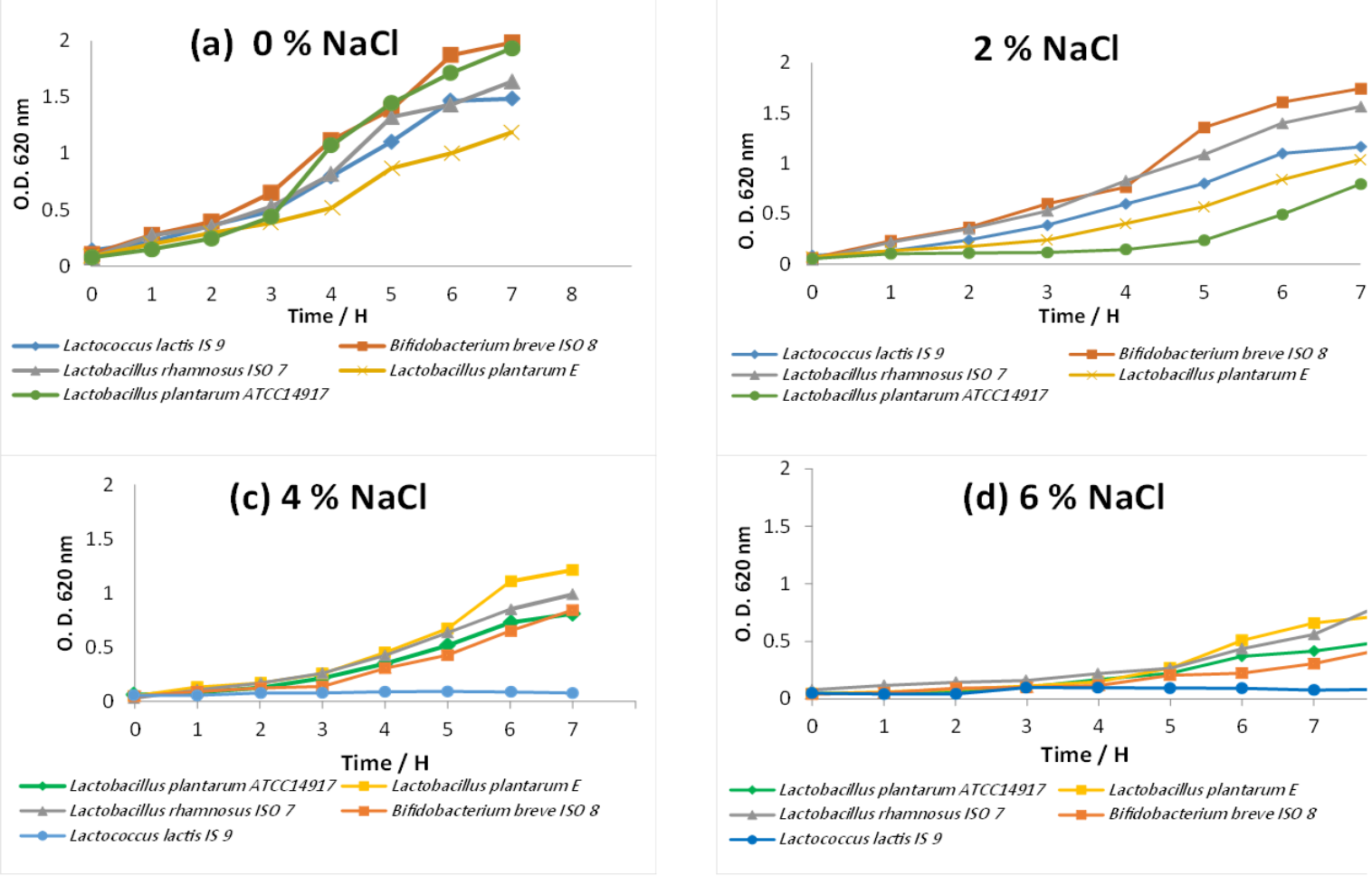

Figure 1. (a-d): Effect of $\mathrm{NaCl}$ concentrations on the growth of some probiotic bacteria

\section{Acidity (\%) and pH development:}

Development of acidity and the change of $\mathrm{pH}$ produced by the tested probiotic strains of the slurry during incubation are presented in Figure 2. Acidity development nearly still occurred within the first 2 hours followed by slightly increase with the same rate for all the tested probiotic strains within the next 2 hours (Figure 2a). After the first four hours, acidity developed with wide different rates for the tested strains, and Bifidobacterium breve ISO8 recorded the highest acidity development among the last incubation time $(8-10 \mathrm{hr})$, Lactococcus lactis also recorded the highest acidity within the middle incubation time (4-10 hr). The lowest acidity development was recorded for Bifidobacterium breve ISO 8 within the first incubation time (4-8 hr) (Figure 2a). On the other hand, the $\mathrm{pH}$ values recorded by all tested strains (Figure 2b) took an opposite trend to that of acidity as mentioned by ELAlfy et al. (2018). Increasing of acidity followed by decreasing of $\mathrm{pH}$ attributed to formation of acids during incubation especially lactic acid as a result of microorganisms' metabolism (Abd EL-Gaber 2019). a)

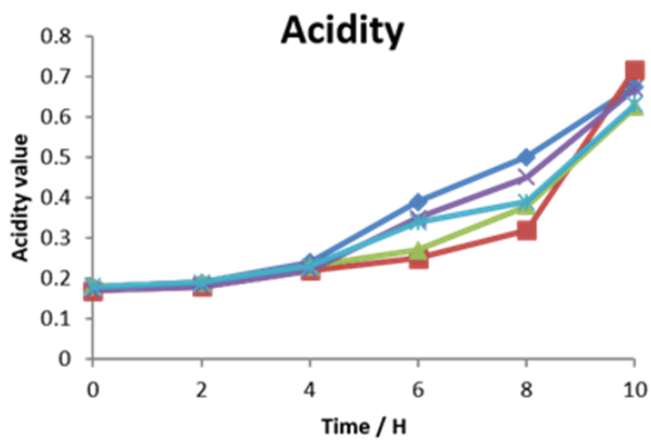

- Lactococcus lactis is $9 \quad-$ Bifidobacterium breve Iso 8
- Lactobacillus rahmnosus Iso $7 \rightarrow$ Lactobacillus plantarum $E$
- Lactobacillus plantarum 16 b)

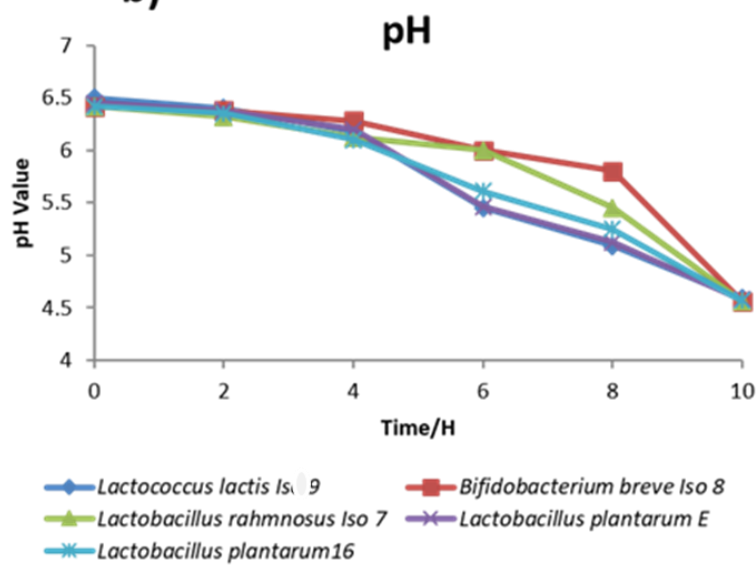

Figure 2. ( $\mathrm{a}$ and $\mathrm{b}$ ): Development of acidity and the change in $\mathrm{pH}$ produced by some probiotic bacteria 
Chemical composition of cheese slurry made with some probiotic strains:

The gross chemical composition of cheese slurry during incubation for 7 days at $40^{\circ} \mathrm{C}$ displayed in Table (1).

The total solid contents of fresh prepared cheese slurry were slightly higher than that of the control and recorded $21.26,21.48,21.33,21.13,21.16$ and $21.20 \%$ for treatments $1-6$, respectively. The total solid contents of incubated slurry for 7 days at $40^{\circ} \mathrm{C}$ were slightly increased compared with same treatments at the beginning of incubation period and recorded 22.15, 21.93, 22.49, 22.43, 22.62 and $22.64 \%$ for the same previous order, such increase due to the loss of some moisture by evaporation during incubation and this are confirmed by EL-Alfy et al. (2011).
The fat content for fresh prepared cheese slurry of different treatments with different probiotic strains were $10 \%$ for the control and all other samples, whereas the fat content of cheese slurry at the end of incubation ( 7 days at $40^{\circ} \mathrm{C}$ ) was slightly increased. This could be attributed to the increase of total solids via loss of some moisture (Abd EL- Gaber 2019).

The protein content of fresh and incubated cheese slurry for 7 days at $40^{\circ} \mathrm{C}$ of different tested strains which were increased after incubation for 7 days with a slight difference among the treatments, such increase suggested to be due to the increase in total solids (EL-Alfy et al., 2018). The variance of protein content among treatments may be attributed to the proteolysis take place during cheese slurry incubation.

Table 1. Gross chemical composition and $\mathrm{pH}$ values \& Acidity of cheese slurry during incubation at $40^{\circ} \mathrm{C}$ up to 7 days

\begin{tabular}{llllllllll}
\hline $\begin{array}{l}\text { Storage period } \\
\text { (days) }\end{array}$ & $\begin{array}{l}\text { Sample } \\
\text { NO }\end{array}$ & T.S\% & Fat\% & Protein\% & SN\% & Ash\% & CHO\% & Acidity\% & pH \\
\hline Start & Control & 21.26 & 10.00 & 8.50 & 0.26 & 1.51 & 1.47 & 0.79 & 6.20 \\
& T1 & 21.48 & 10.00 & 8.40 & 0.28 & 1.52 & 1.43 & 0.81 & 5.95 \\
& T2 & 21.33 & 10.00 & 8.40 & 0.25 & 1.53 & 1.42 & 0.78 & 5.84 \\
& T3 & 21.13 & 10.00 & 8.65 & 0.25 & 1.53 & 1.37 & 0.82 & 5.66 \\
& T4 & 21.16 & 10.00 & 8.50 & 0.26 & 1.55 & 1.35 & 0.84 & 5.44 \\
& T5 & 21.20 & 10.00 & 8.35 & 026 & 1.56 & 1.47 & 0.85 & 5.47 \\
\hline End & Control & 22.15 & 10.50 & 8.15 & 0.27 & 1.45 & 1.63 & 1.16 & 4.22 \\
& T1 & 21.93 & 10.50 & 8.35 & 027 & 1.45 & 1.80 & 1.43 & 4.21 \\
& T2 & 22.49 & 10.50 & 8.25 & 0.27 & 1.49 & 2.04 & 1.14 & 4.14 \\
& T3 & 22.43 & 11.00 & 8.20 & 0.27 & 1.53 & 1.46 & 1.67 & 3.47 \\
& T4 & 22.62 & 11.00 & $8 . .05$ & 0.28 & 1.52 & 1.57 & 1.61 & 3.45 \\
& T5 & 22.64 & 11.00 & 8.00 & 0.28 & 1.56 & 1.43 & 1.44 & 3.68 \\
\hline
\end{tabular}

Control; Yoghurt starter (T1) Control+ Lc. lactis IS9; (T2) Control + B. breve ISO8; (T3) Control + L. rhamnosus ISO7; (T4) Control + L. plantarum E; (T5) Control + L. plantarum ATCC14917.

The carbohydrate content of cheese slurry slightly decreased during the incubation for 7 days at $40^{\circ} \mathrm{C}$, and this may be due to the CHO hydrolysis and formation of acid mainly lactic acid. The obtained results are in accordance with that obtained by (Abdel-Baky et al.., 1982 and EL-Shafei (2015).

\section{Microbiological Properties of the prepared cheese slurry made with some probiotic strains:}

Total bacterial, Proteolytic and lipolytic bacterial counts in fresh and incubated cheese slurry at $40^{\circ} \mathrm{C}$ for 7 days are given in Table (2). The total bacterial count of the tested strains recorded 7.2, $6.67,6.85,7.0,6.93$ and 7.0 in the first day of incubation of the cheese slurry. The obtained results revealed that there are an increase of total bacterial counts during the incubation time up to 7 days at $40^{\circ} \mathrm{C}$ to be $7.65,7.58,7.88,8.3,8.11$ and 8.18 for $\mathrm{C}$, $\mathrm{T} 1, \mathrm{~T} 2, \mathrm{~T} 3, \mathrm{~T} 4$ and T5 $\log \mathrm{cfu} \mathrm{g}^{-1}$, in the same order. The proteolytic and lipolytic bacterial counts of cheese slurry also increased and reached its highest counts at the end of incubation after 7 days at $40^{\circ} \mathrm{C}$, and the experimental cheese slurry treatments recorded the highest counts than the control.

In general, the counts of all bacterial groups (Total bacterial, proteolytic and lipolytic bacterial counts) were increased throughout the incubation period at different rates and there were difference in counts among the control and other treatments of cheese slurry. Moreover, the highest counts were recorded for all the tested microorganisms, the total bacterial counts and lipolytic and proteolytic bacterial counts, by the end of incubation time. The obtained results agreed with that obtained by EL-Sayed and Abbas (1992), and EL- Shafei (2015). 
Table 2. Total bacterial counts*, proteolytic and lipolytic counts $\left(\log \mathrm{cfu} \mathrm{g}^{-1}\right)$ of cheese slurry made with different probiotic strains during incubation for 7 days at $40^{\circ} \mathrm{C}$

\begin{tabular}{|c|c|c|c|c|}
\hline \multirow[b]{2}{*}{ Treatments } & \multicolumn{2}{|c|}{ Total bacterial counts* } & \multirow[b]{2}{*}{$\begin{array}{l}\text { Proteolytic bacterial } \\
\text { count (End of } \\
\text { incubation) }\end{array}$} & \multirow[b]{2}{*}{$\begin{array}{c}\text { Lipolytic bacterial } \\
\text { count } \\
\text { (End of incubation) }\end{array}$} \\
\hline & $\begin{array}{l}1^{\text {st }} \text { day of } \\
\text { incubation }\end{array}$ & $\begin{array}{c}\text { End of } \\
\text { incubation } \\
\text { (7days) }\end{array}$ & & \\
\hline Control & 7.20 & 7.65 & 7.30 & 7.00 \\
\hline T1 & 6.67 & 7.58 & 7.20 & 7.30 \\
\hline $\mathbf{T 2}$ & 6.85 & 7.88 & 7.56 & 7.48 \\
\hline T3 & 7.00 & 8.30 & 7.20 & 7.72 \\
\hline T4 & 6.93 & 8.11 & 8.60 & 8.52 \\
\hline T5 & 7.00 & 8.18 & 8.56 & 8.41 \\
\hline
\end{tabular}

*Counts are Three replicate, Control: yoghurt starter (L. delbruckii subsp bulgaricus and Str. thermophiles), T1: yoghurt starter + Lactococcus lactis IS9, T2: yoghurt starter + B. breve ISO8, T3: yoghurt starter +L. rhamnosus ISO7, T4: yoghurt starter + L. Plantarum E, and T5: yoghurt starter + L. plantarum. ATCC14917.

\section{Sensory evaluation:}

The cheese slurry samples were evaluated for different organoleptic properties and the panelist score are presented in Table (3). According to the obtained results, the control recorded the lowest score than the other slurry treatments. The fresh samples of slurry recoded lower score than that incubated for 7 days at $40^{\circ} \mathrm{C}$, and it was found that T5 L. plantarum ATCC14917 recorded the highest score either when fresh or after incubation time. Much lower score values were observed for treatment 2 (Lactococcus lactis IS9. The incubation for 7 days at $40^{\circ} \mathrm{C}$ recorded the maximum score values for the control and all other treatments. On the other hand, increasing of incubation time will produce undesirable flavour with excessive acidity and it seemed to be unacceptable. Also, it may be related with the appearance of bitterness or rancidity (over ripening) as recorded by Mehanna et al .(2009) and EL-shafei (2015).

Fatty acids profile of cheese slurries made with different probiotic strains:

Table (4) and Fig (3) shows the fatty acids profile of cheese slurries made with some probiotic lactic acid bacteria. The results of fatty acids revealed that, the saturated fatty acids (SFAs) in control slurry recorded the lowest proportion (62.55\%), while slurry made with Lactococcus lactis recorded the highest proportion (64.78\%). Moreover, the proportion of short and medium chain fatty acids were increased, particularly, butyric acid (C4:0) which increased from $0.45 \%$ in control slurry to be $3.08,1.27,1.16$ and $1.43 \%$ in slurries made with Lac. Lactis IS9, B. breve ISO8, L. rhamnosus ISO7, L. plantarum E and L. plantarum ATCC14917, respectively.

The benefit of the produced butyrate that it plays essential roles in cell growth control differentiation and prevention of tumor genesis in colon cells (Dhankhar et al., 2016), butyric acid also contributes to the maintenance of the gut barrier functions and has anti-inflammatory and immunomodulatory properties (Riviere et al., 2016). On the other hand, short chain fatty acids have high rate of digestibility and play an important role in reduction of triglycerol levels as well as cholesterol level in blood and liver (Hara et al., 1999 ) and (Fushimi et al .,2006 ).

From technological and organoleptic aspects, short-chain fatty acids are considered to be the most components responsible for flavor development in slurries and cheese (Kwak et al., 2002) and that was noticeable from organoleptic testing. The monounsaturated and poly-unsaturated fatty acids nearly had no change or kept around their level in the control slurry which have health benefits for human body and play an important roles in preventing and/ or treatment of different diseases i.e. hypertension, coronary heart diseases, inflammatory, cancer, thrombotic diseases and autoimmune disorders and as well as type II diabetes, ulcerative colitis and crohn's disease. Tokusoglu and Zcan (2005); Simopoulos, (2009) and Ortega et al. (2018). 
Table 3. Sensory evaluation score of cheese slurry made with different probiotic strains during incubation period up to 7 days at $40^{\circ} \mathrm{C}$

\begin{tabular}{|c|c|c|c|c|c|}
\hline Treatment & Storage period (day) & Flavour (60) & Body Texture (40) & Total & Average score \\
\hline \multirow{6}{*}{ Control } & \multirow{3}{*}{1} & 54 & 24 & 78 & \multirow{3}{*}{77} \\
\hline & & 53 & 23 & 76 & \\
\hline & & 52 & 25 & 77 & \\
\hline & \multirow{3}{*}{7} & 53 & 24 & 77 & \multirow{3}{*}{77} \\
\hline & & 52 & 26 & 78 & \\
\hline & & 54 & 23 & 77 & \\
\hline \multirow{6}{*}{$\mathbf{T 1}$} & \multirow{3}{*}{1} & 52 & 25 & 77 & \multirow{3}{*}{78} \\
\hline & & 53 & 25 & 78 & \\
\hline & & 55 & 23 & 78 & \\
\hline & \multirow{3}{*}{7} & 55 & 24 & 79 & \multirow{3}{*}{78} \\
\hline & & 54 & 23 & 78 & \\
\hline & & 51 & 25 & 76 & \\
\hline \multirow{6}{*}{$\mathbf{T 2}$} & \multirow{3}{*}{1} & 55 & 35 & 90 & \multirow{3}{*}{90} \\
\hline & & 56 & 34 & 90 & \\
\hline & & 54 & 36 & 90 & \\
\hline & \multirow{3}{*}{7} & 56 & 35 & 91 & \multirow{3}{*}{92} \\
\hline & & 55 & 36 & 91 & \\
\hline & & 56 & 37 & 93 & \\
\hline \multirow{6}{*}{ T3 } & \multirow{3}{*}{1} & 57 & 35 & 92 & \multirow{3}{*}{93} \\
\hline & & 56 & 37 & 93 & \\
\hline & & 58 & 36 & 94 & \\
\hline & \multirow{3}{*}{7} & 56 & 36 & 92 & \multirow{3}{*}{93} \\
\hline & & 57 & 36 & 93 & \\
\hline & & 56 & 37 & 93 & \\
\hline \multirow{6}{*}{ T4 } & \multirow{3}{*}{1} & 55 & 38 & 93 & \multirow{3}{*}{94} \\
\hline & & 56 & 38 & 94 & \\
\hline & & 58 & 37 & 95 & \\
\hline & & 57 & 36 & 93 & \multirow{3}{*}{94} \\
\hline & 7 & 57 & 37 & 94 & \\
\hline & & 56 & 37 & 94 & \\
\hline \multirow{6}{*}{ T5 } & & 60 & 37 & 97 & \multirow{3}{*}{97} \\
\hline & 1 & 59 & 38 & 97 & \\
\hline & & 58 & 38 & 96 & \\
\hline & \multirow{3}{*}{7} & 58 & 38 & 96 & \multirow{3}{*}{96} \\
\hline & & 59 & 37 & 96 & \\
\hline & & 57 & 38 & 95 & \\
\hline
\end{tabular}

Control; Yoghurt starter (T1) Control + Lc. lactis Is 9; (T2) Control + B. breve Iso8; (T3) Control + L. rhamnosus Iso 7 ; (T4) Control+ L. plantarum E; (T5) Control + L. plantarum ATCC14917. 
Table 4. Fatty acids composition of cheese slurries made with different probiotic strains

\begin{tabular}{|c|c|c|c|c|c|c|c|}
\hline \multirow{2}{*}{$\begin{array}{l}\text { Fatty acids } \\
\text { Common name }\end{array}$} & \multirow[b]{2}{*}{ Formula } & \multicolumn{6}{|c|}{ Fatty acids of slurries $(\%)$} \\
\hline & & Control & T1 & T2 & T3 & T4 & T5 \\
\hline \multicolumn{8}{|l|}{ SFAs } \\
\hline Butyric & $\mathrm{C4:0}$ & 0.45 & 3.08 & 1.27 & 1.81 & 1.16 & 1.43 \\
\hline Caproic & C6:0 & 1.81 & 2.15 & 1.59 & 1.75 & 1.54 & 1.68 \\
\hline Caprylic & C8:0 & 1.02 & 1.17 & 0.92 & 0.99 & 0.91 & 0.95 \\
\hline Capric & C10:0 & 2.07 & 2.29 & 1.93 & 2.05 & 1.92 & 1.97 \\
\hline Lauric & C12:0 & 2.61 & 2.77 & 2.45 & 2.57 & 2.49 & 2.53 \\
\hline Myristic & C14:0 & 11.33 & 11.65 & 10.84 & 11.23 & 11.12 & 11.22 \\
\hline Pentadecanoic & C15:0 & 1.43 & 1.39 & 1.37 & 1.41 & 1.39 & 1.41 \\
\hline Palmitic & C16:0 & 28.86 & 28.17 & 28.76 & 28.61 & 28.72 & 28.72 \\
\hline Margaric & C17:0 & 0.84 & 0.78 & 0.9 & 0.85 & 0.9 & 0.84 \\
\hline Stearic & C18:0 & 11.68 & 10.9 & 12.36 & 11.84 & 12.05 & 11.93 \\
\hline Arachidic & C20:0 & 0.28 & 0.26 & 0.34 & 0.31 & 0.34 & 0.31 \\
\hline Behenic & C22:0 & 0.17 & 0.17 & 0.19 & 0.18 & 0.19 & 0.18 \\
\hline TSFAs & & 62.55 & 64.78 & 62.92 & 63.6 & 62.73 & 63.17 \\
\hline \multicolumn{8}{|l|}{ MUFAs } \\
\hline Myristoleic & C14:1 & 0.91 & 0.89 & 0.51 & 0.92 & 0.86 & 0.95 \\
\hline Pentadecenoic & C15:1 & 0.45 & 0.43 & 0.44 & 0.44 & 0.45 & 0.45 \\
\hline Palmitoleic & C16:1 & 1.55 & 1.58 & 1.59 & 1.52 & 1.66 & 1.51 \\
\hline Heptadecenoic & C17:1 & 0.29 & 0.27 & 0.36 & 0.30 & 0.35 & 0.30 \\
\hline Eicosenoic & C20:1 & 0.28 & 0.26 & 2.34 & 0.33 & 0.33 & 0.32 \\
\hline Oleic & C18:1 & 27.24 & 25.63 & 27.02 & 26.56 & 27.11 & 26.97 \\
\hline TMUFAs & & 30.72 & 29.06 & 32.26 & 30.07 & 30.76 & 30.50 \\
\hline \multicolumn{8}{|l|}{ PUFAs } \\
\hline Linoleic & C18:2 & 2.22 & 2.06 & 2.08 & 2.08 & 2.19 & 2.08 \\
\hline$\alpha$-Linolenic & C18:3n3 & 0.45 & 0.41 & 0.45 & 0.44 & 0.47 & 0.44 \\
\hline Stearidonic acid & C18:4 & 1.33 & 1.24 & 1.35 & 1.33 & 1.37 & 1.35 \\
\hline TPUFAs & & 31.24 & 29.34 & 30.9 & 30.41 & 31.14 & 30.84 \\
\hline TUFAs & & 34.72 & 32.77 & 36.14 & 33.92 & 34.79 & 34.37 \\
\hline Total unknown & & 2.730 & 2.430 & 2.940 & 2.470 & 2.480 & 2.460 \\
\hline
\end{tabular}

Control: Yoghurt starter (T1): Control +Lc. lactis Is 9; (T2): Control + B. breve Iso8; (T3): Control + L. rhamnosus Iso 7; (T4): Contol+ L. plantarum E; (T5): Control + L. plantarum ATCC14917(16). (SFAs) Saturated fatty acids; (MUFAs) Mono unsaturated fatty acids; (PUFAs) Poly unsaturated fatty acids; (UFAs) Unsaturated fatty acids. 


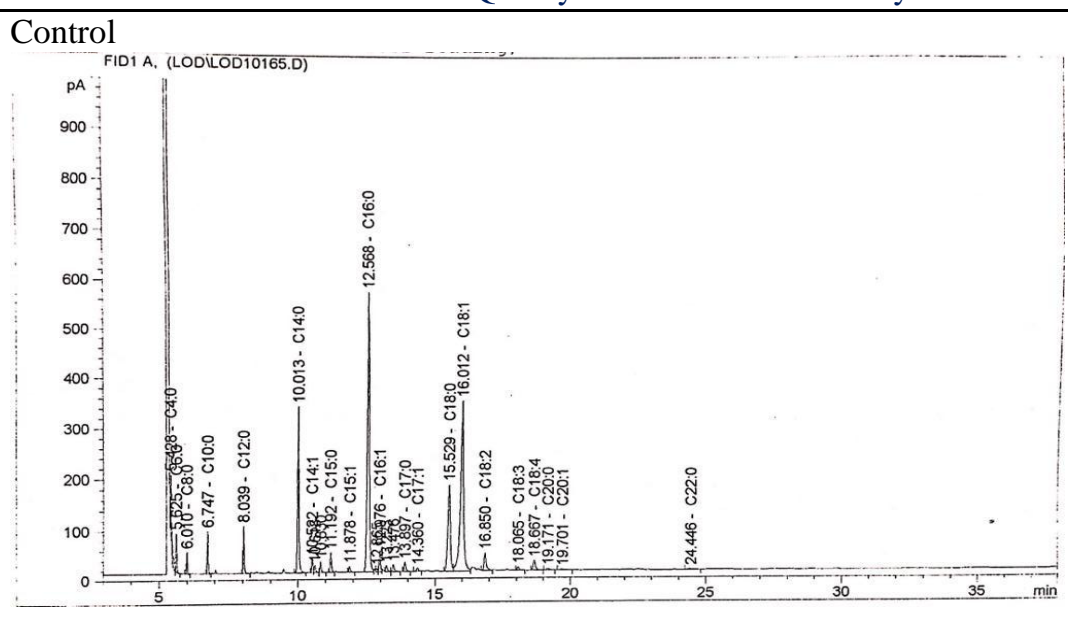

\section{(T1) Lac. lactis IS9}

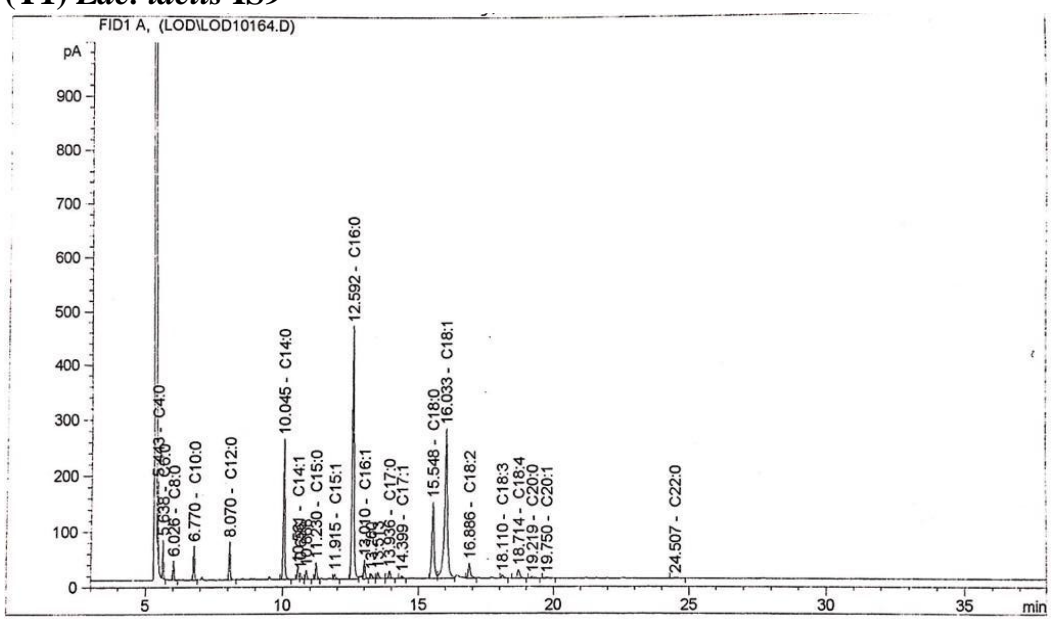

(T2) B. breve ISO8

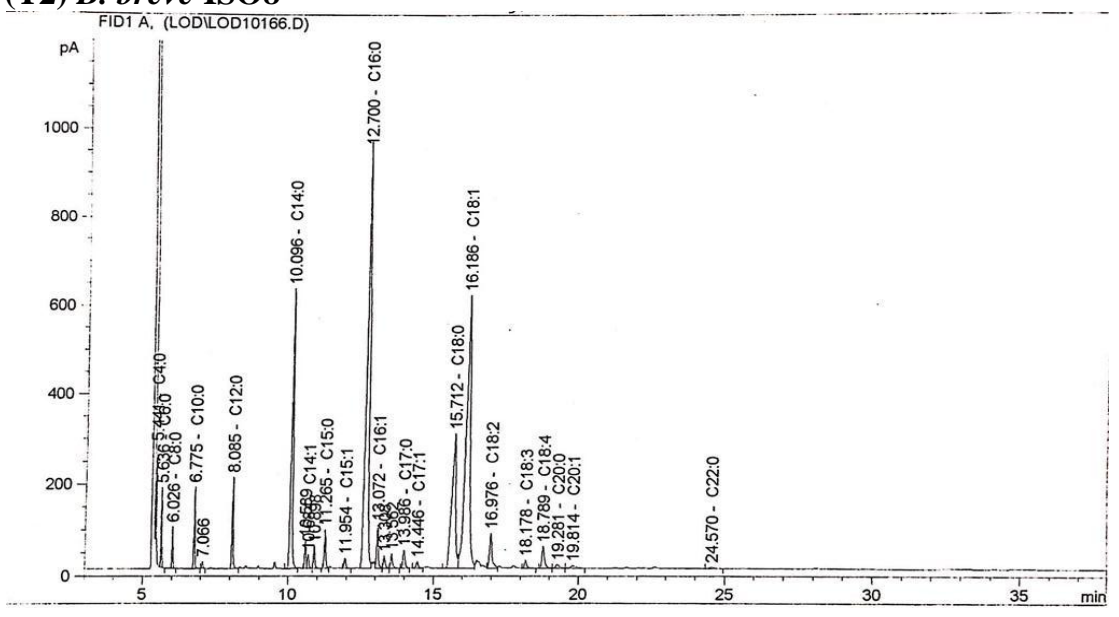

Fig (3) Chromatogram of fatty acids composition from cheese slurries made with different probiotic strains Control: Yoghurt starter (T1) Control + Lc. lactis IS9; (T2) Control + B. breve ISO8. 

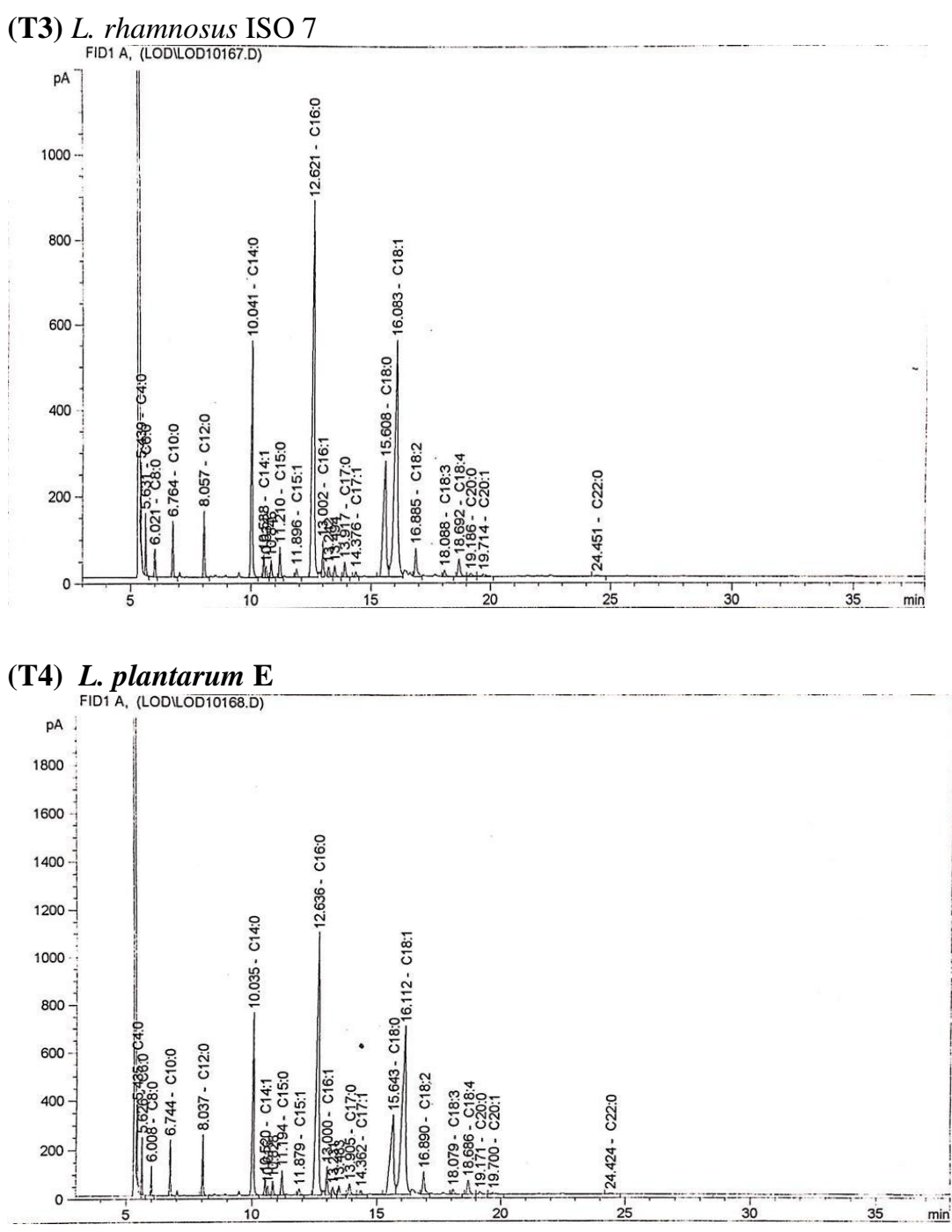

(T5) L. plantarum ATCC14917 (16)

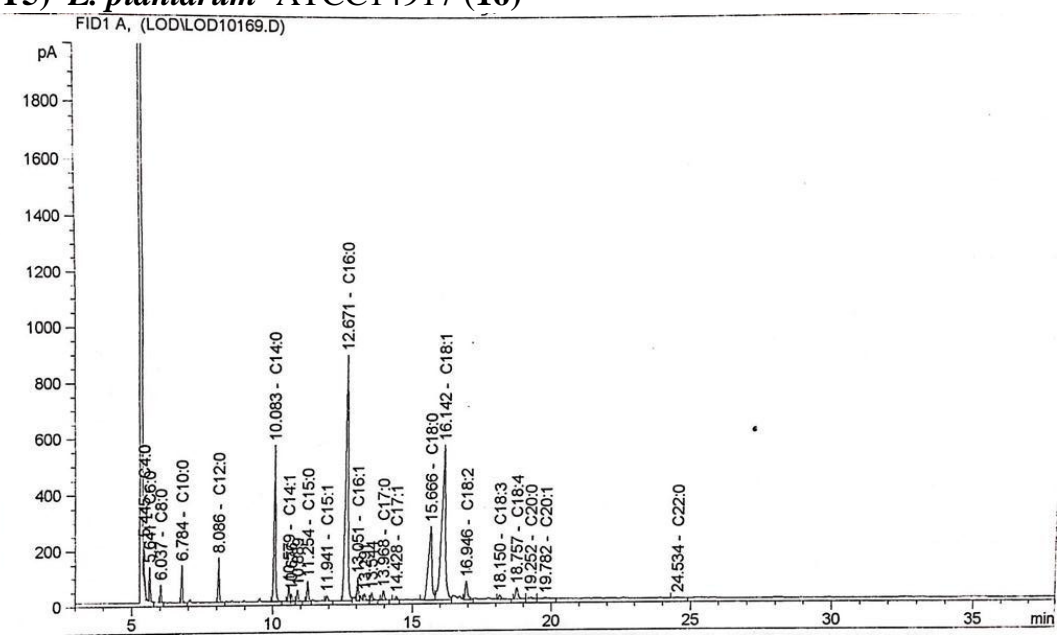

Fig. (3) Continued Chromatogram of fatty acids composition from cheese slurries made with different probiotic isolates. (T3): Control + L. rhamnosus ISO7; (T4): Control+ L. plantarum E; (T5): Control + L. plantarum ATCC14917. 


\section{Individual Free Amino Acid Composition}

The content of free amino acids in test samples of cheese slurry on $7^{\text {th }}$ day of ripening is illustrated by Table (5). The results showed that essential free amino acids in the samples of cheese slurry were, Histadine, Lysine, Leucine, Isoleucine, Methionine, Valine, Phenylalanine and Therionine, respectively. With the most pronounced differences noted for Lysine, Leucine Valine acids.

Total non- essential amino acid contents of the cheese slurry are presented in Table (5) had significant effects on total free amino acid contents of the cheeses. Total free amino acid contents of the cheese slurry differ due to the differences of probiotic strains used in making the cheese Faster increases were also reported in total free amino acid levels throughout the ripening process overall characteristic flavor of different strains varieties and describe how far the ripening has proceeded. As compared to the control essential amino acids significantly higher in all the treatments contains probiotics amino acid concentrations on the $7^{\text {th }}$ day of ripening. On the other hand, non- essential amino acids i.e (Aspartic, Serine, Glutamic, Glycine, Alanine, Tyrosine, Argnine, Proline and Cysteine). Also, there was an increase in Glutamic and Proline. Shenana and Patel (2020).

Table 5. Amino acids profile of cheese slurry made with different probiotic strains

\begin{tabular}{|c|c|c|c|c|c|c|}
\hline \multirow{2}{*}{$\begin{array}{l}\text { Amino acid } \\
\text { Essential }\end{array}$} & \multicolumn{5}{|c|}{ Amino acids profile of cheese slurry (\%) } & \multirow[b]{2}{*}{ T5 } \\
\hline & Control & T1 & T2 & T3 & T4 & \\
\hline Histadine (HIS) & 0.22 & 0.26 & 0.29 & 0.22 & 0.22 & 0.18 \\
\hline Lysine (LYS) & 0.58 & 0.70 & 0.76 & 0.58 & 0.57 & 0.49 \\
\hline Leucine (LEU) & 0.67 & $\mathbf{0 . 8 3}$ & 0.91 & 0.65 & 0.64 & 0.55 \\
\hline Isoleucine (ILE) & 0.38 & 0.48 & 0.49 & 0.33 & 0.33 & 0.29 \\
\hline Methionine (met) & 0.26 & 0.24 & 0.31 & 0.23 & 0.22 & 0.18 \\
\hline Valine (VAL) & 0.50 & 0.58 & 0.53 & 0.40 & 0.40 & 0.34 \\
\hline Phenylalanine (PHE) & 0.39 & 0.46 & 0.49 & 0.37 & 0.37 & 0.30 \\
\hline Therionine (THR) & 0.32 & 0.36 & 0.41 & 0.30 & 0.28 & 0.26 \\
\hline \multicolumn{7}{|l|}{ Non-essential } \\
\hline Aspartic (ASP) & 0.52 & 0.61 & 0.74 & 0.49 & 0.45 & 0.41 \\
\hline Serine (SER) & 0.39 & 0.46 & 0.47 & 0.37 & 0.33 & 0.32 \\
\hline Glutamic (GLU) & 1.46 & 1.73 & 2.23 & 1.43 & 1.40 & 1.25 \\
\hline Glycine (GLY) & 0.16 & 0.17 & 0.17 & 0.13 & 0.12 & 0.11 \\
\hline Alanine (ALA) & 0.31 & 0.38 & 0.31 & 0.22 & 0.21 & 0.19 \\
\hline Tyrosine (TYR) & 0.16 & 0.25 & 0.36 & 0.11 & 0.15 & 0.04 \\
\hline Argnine (ARG) & 0.25 & 0.29 & 0.28 & 0.25 & 0.24 & 0.21 \\
\hline Proline (PRO) & 0.89 & 1.07 & 1.20 & 0.85 & 0.82 & 0.74 \\
\hline Cysteine (cys) & 0.05 & 0.09 & 0.30 & 0.09 & 0.17 & 0.06 \\
\hline
\end{tabular}

Control; Yoghurt starter (T1) Control + Lc. lactis Iso 9; (T2) Control + B. breve Iso8; (T3) Control $+L$. rhamnosus Iso 7; (T4) Control + L. plantarum E; (T5) Control + L. plantarum ATCC14917.

\section{Conclusion}

The use of probiotic bacteria e.g. B. breve, $L$. rhamnosus, L. plantarum strongly develops cheese slurry system with good proteolytic and lipolytic properties. Cheese slurry can be an effective vehicle to deliver the probiotic microorganisms to cheese. From technological and organoleptic aspects, cheese slurry containing L. rhamnosus Iso7 and L. plantarum ATCC 14917 are the most suitable candidates to be applicable to wide variety of cheeses.

\section{Reference}

Abd-EL-Hamid L .B; Mahran G . A.; Abas H .A and Hofei ; A . A(1991) A simple production condition for Ras cheese slurry. Egypt. J Dairy Sci 9, p.327.
Abd EL-Gaber (2019). Studies on producing some therapeutic Dairy products. Ph.D . Thesis Benha Univ., Egypt.

Abdel Baky, A. A., ELF AK, A. M., Rabie, A. M., \& El Neshewy, A. A. (1982). Cheese slurry in the acceleration of Cephalotyre "Ras" cheese ripening. Journal of food protection, 45(10), 894897.

APHA (2004). American Public Health Association. Standard methods for the examination of dairy products. American Publ.

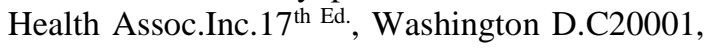
USA.

AOAC, (2012). Official methods of Analysis of Association of Official Analytical Chemists $1^{\text {th }}$ ed., Published by AOAC International, Gaithersburg, Maryland 20877-2414, USA.

AOAC (2016). Official methods of Analysis of Association of Official Analytical Chemists $20^{\text {th }}$ 
ed NO 994. 12 chapter 1 p online Determination of Total Amino Acids (TAA)

BSI (1989). British Standards Institution. Chemical analysis of cheese. BSI, 770.

Dhankhar, J., Sharma, R., \& Indumathi, K. P. (2016). Bioactive lipids in milk. International Food Research Journal, 23(6), 2326.

EL-Alfy, M. B, EL-Nagar, G. F.; Abd El- Aty, M.A.; Essawy, E. A. and Hammad, M. N. A. (2018). Making of fortified yoghurt with colostrum Egypt. J. Appl. Sci. 33 (3) 61-75.

EL-Alfy, M. B.; Shenana, M. E; Abd EL-Aty, M. A. and ElKhtab, E. S. (2011). Antibacterial activity of some natural preservative material and their effects characterestics of yoghurt. Egypt. J Appl. Sci. 26 (12B) 343-360.

EL-Sayed, N. H and Abbas, H. M. (1992). Effect of milk on the properties of Ras cheese slurries. Egyptian J. Dairy Sci. 20, p. 371.

EL-Shafei, S. (2015). Technological study on Goats milk Thesis Ph. D. Benha Univ., Egypt.

EL-Wahsh, N. (2013). A study on production and attributes of some dairy products as functional foods. Ph.D. Thesis, Tanta University, Egypt.

Fitzsimons, N. A., Cogan, T. M., Condon, S., and Beresford, T. (1999). Phenotypic and genotypic characterization of non-starter lactic acid bacteria in mature cheddar cheese. Appl. Environ. Microbiol. 65, 3418-3426.

Fushimi, T.; Suruga, K.; Oshima, Y.; Fukiharu, M.; Tsukamoto, Y.; Goda, T. (2006). Dietary acetic acid reduces serum cholesterol and triacylglycerols in rats fed a cholesterol-rich diet. Br. J. Nutr, 95, 916-924

Gobbetti, M., De Angelis, M., Di Cagno, R., Mancini, L., and Fox, P. F. (2015). Pros and cons for using non-starter lactic acid bacteria (NSLAB) as secondary/adjunct starters for cheese ripening. Trends Food Sci. Tech. 45, 167-178. doi: 10.1016/j.tifs.2015.07.016.

Hara, H.; Haga, S.; Aoyama, Y.; Kiriyama, S. (1999). Short-chain fatty acids suppress cholesterol synthesis in rat liver and intestine. J. Nutr. 129, 942-948.

Harper, W. J. and Krisoffersen, T (1970). Biochmical Aspeects Flavor Development in Cheddear Cheese Slurries. J. AGR. FOOD CHEM., VOL.18, NO. 4.

Hofi A.A.; Mahran G.A.; Abd EL-Salam M.H. and Rifaat I.D. (1973). Acceleration of Cephalotyre (Ras) cheese ripening by using trace elements I. experiments. Egypt. J. Dairy Sci. 1, p.33.

Hofi, A. A., Hamid, L. A., Ahmed, N. S., \& Abbas, H. M. (1991). Acceleration of Ras cheese ripening by relevant slurry. Egyptian J. Dairy Sci., 19(12), 337-346.

IDF (1987). International Dairy Federation Skimmed milk, whey and butter milk.
Determination of fat content. Rose gottieb Gravimetric Methods .IDF.22B.

IDF (1997). Sensory evaluation of dairy products by scoring reference method. Standard $99 \mathrm{C}$

IDF, (1991). Butter, fermented milks and fresh cheese. Enumeration of contaminating microorganisms. Colony count technique at $30^{\circ} \mathrm{C}$. International Dairy Federation Standard, 153.

IDF(1996). Milk. Determination of fat content.00ID.

Ismail, E .A. (2007). Characterization and genetic improvement of Lactobacilli for Application in Probiotic Dairy products Ph.D. thesis, Kiel University, Kiel-Germany.

ISO (2011) Official methods 12966-2 Determination of free fatty Acids (FAA)

Kwak, H. S., Chung, C. S., \& Ahn, J. (2002). Flavor compounds of cholesterol-reduced Cheddar cheese slurries. Asian-australasian journal of animal sciences, 15(1), 117-123.

Mehanna, N. M. Mousa, M. A. and Abd EL Khair, A. A. (2009) Improvement of Ras cheese made from pasteurized milk using slurry from ewes milk cheese. Egypt J. Dairy Sci. p. 37.

Ortega J. A. A, Cansino N. S. C., Moreno E. R. and Olivares L. D. (2018) Bioactive properties of the lipids of cow milk on human health. Approaches in Poultry, Dairy \& C Veterinary Sciences 5 (2): 1-2.

Rivière, A., Selak, M., Lantin, D., Leroy, F., \& De Vuyst, L. (2016). Bifidobacteria and butyrateproducing colon bacteria: importance and strategies for their stimulation in the human gut. Frontiers in microbiology, 7.

SAS Institute (1990). SAS User's Guide/STAT ver. 6.04 Fourth edition SAS Inst. Inc., Cary, NC., USA.

Shenana, M. E. and Patel, A, R. (2020) Starter Cultures: Classification, Traditional Production Technology, and Potential Role in Cheese Manufacturing Industries. Chapter 2 In : Microbiology for Food and Health Technological Developments and Advances. Editors: Deepak Kumar Verma and Ami R. Patel Prem Prakash Srivastav, PhD Balaram Mohapatra Alaa Kareem Niamah, PhD. Publisher: Apple Academic Press; $1^{\text {st }}$ edition (January 20, 2020).

Simopoulos, A.P. (2009). Human requirement for n3 polyunsaturated fatty acids, Symposium: Role of poultry products in enriching the human diet with N-3 PUFA. Poultry Science 79:961-970.

Stefanovic E., Kilcawley K. N, Roces C, Rea M. C., O'Sullivan M., Sheehan J. J. and McAuliffe O. (2018). Evaluation of the Potential of Lactobacillus paracasei Adjuncts for Flavor Compounds Development and Diversification in Short-Aged Cheddar Cheese. Frontiers in Microbiology, 9 (1506):1-12.

Tokusoglu O“, O* zcan C. (2005). Egg yolk and breast milk based long chain-polyunsaturated fatty acids (LC-PUFA): Nutraceutical and clinical 
aspects. Oral presentation. Practical short course: Specialty and functional oils: Consumer perceptions, market trends and health, $8^{\text {th }}-9^{\text {th }}$ December, University of Ghent, Ghent, Belgium.

$$
\begin{aligned}
& \text { تأثير بعض بكتريا الأعمة للحيوية علي الطعم والنكهه و جودة خثرة الجبن الطازج }
\end{aligned}
$$

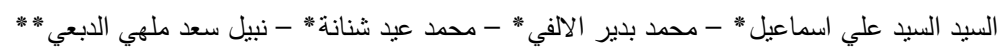

$$
\begin{aligned}
& \text { *قمم الألبان - كلية الزراعة بمشتهر - جامعة بنها - ** قسم علوم وتكنولوجيا الأغذية - كلية الزراعة- جامعة اب -جمهورية اليمن } \\
& \text { ويهذف هذا البحث الى دراسة تحمل خمسة من السلالات الداعمة الحيوية لظروف النمو والتصنيع (تحمل ملح كلوريد الصوديوم - } \\
& \text { الحموضة - الـpH و دراسة تأثير استخدامها كبادئات مساعدة في صناعة خثرة الجين والسلالات المستخدمة هي: }
\end{aligned}
$$

Lactococcus lactis IS9, Bifidobacterium breve ISO8, Lactobacillus rhamnosus ISO7, Lactobacillus plantarum E and Lactobacillus plantarum ATCC 14917.

هذا وقد تم دراسة تأثر السلالات بالتركيزات المختلفه لكلوريد الصوديوم وخلصت النتائج الي أن كل السلالات المستخدمة لها القدرة علي

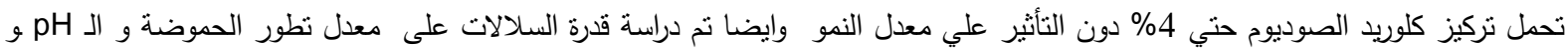

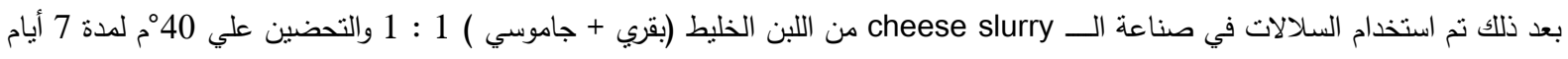
ثم اجراء التحليل الكيماوي - الميكروبيولوجي - الحسي. وسجلت النتائج زيادة طفيفة وبمعدلات مختلفة أثثاء فترة التحضين لكل من الجوامد الكلية، الدهن ، النتروجين الكلى، لكل المعاملات أيضا اظهر التحليل الكيميائى للــــeese slurry الذى تم تحضيرة زيادة مطردة و خصوصـا فى الحموضة ، النتروجين الذائب و الأحماض الدهنية

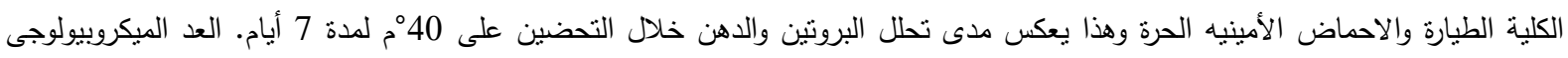

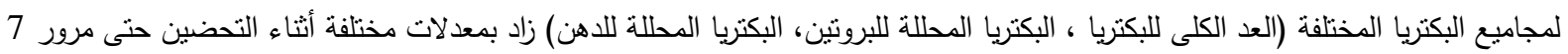

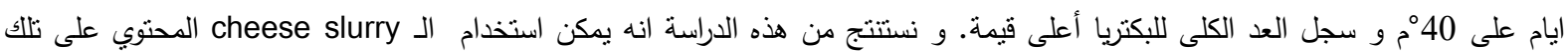

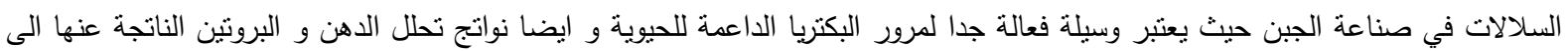

